\author{
Ecology
}

\title{
Recruitment patterns of 2 sea cucumber species in a Central Mexican Pacific coral reef community
}

\author{
Patrón de reclutamiento de 2 holoturoideos asociados a una comunidad coralina del Pacífico \\ central mexicano
}

\author{
Rosa Carmen Sotelo-Casas a , Amilcar Leví Cupul-Magaña ${ }^{a}$, Francisco Alonso Solís-Marín ${ }^{\text {b }}$ \\ Alma Paola Rodríguez-Troncoso ${ }^{\mathrm{a}, *}$ \\ ${ }^{a}$ Laboratorio de Ecología Marina, Centro Universitario de la Costa, Universidad de Guadalajara, Av. Universidad 203, 48280 Puerto Vallarta, Jalisco, Mexico \\ ${ }^{\mathrm{b}}$ Laboratorio de Sistemática y Ecología de Equinodermos, Instituto de Ciencias del Mar y Limnología, Universidad Nacional Autónoma de México, \\ Apartado postal 70-305, 04510 México, D.F., Mexico
}

Received 5 November 2014; accepted 1 September 2015

Available online 13 February 2016

\begin{abstract}
Holothurians are nutrient recyclers, bioturbators, and prey for other taxa in diverse marine ecosystems; thus, they directly impact the distribution of organisms with which they are associated. However, little is known about annual changes in holothurian recruitment. Islas Marietas harbors a coral community with a rich assemblage of holothurians. From March 2011 to February 2012, bimonthly samplings were performed in order to identify the annual recruitment patterns of species Pentamera chierchia and Neothyone gibber. Density (ind $\mathrm{cm}^{-2}$ ) was assessed for each of the 2 species, as was the micro-substrate abutting them. Both species had highest densities in the May and June period $\left(N\right.$. gibber $=0.0903$ ind $\mathrm{cm}^{-2} ; P$. chierchia $=0.0396$ ind $\mathrm{cm}^{-2}$ ); densities $<0.01$ ind $\mathrm{cm}^{-2}$ were documented over the remainder of the year. This is the first record of $P$. chierchia in the study area. Furthermore, no correlation between species density and substrate type was found $(s \leq 0.61, n=7, p>0.05)$. The study of seasonal recruitment fluctuations of reef-associated holothurians and their relationship with factors such as reproduction and availability of coralline substrate may provide information on their life cycles, in order to initially understand some ecological patterns of these species that contribute to the maintenance of regional biodiversity.

All Rights Reserved (C) 2016 Universidad Nacional Autónoma de México, Instituto de Biología. This is an open access item distributed under the Creative Commons CC License BY-NC-ND 4.0.
\end{abstract}

Keywords: Echinoderms; Dendrochirotida; Holothuroidea; Marine invertebrate; Reproduction

\section{Resumen}

Los holoturoideos cumplen funciones como recicladores de nutrientes, bioturbadores y presas de otros taxones en diversos ecosistemas marinos; por lo que afectan directamente la distribución de los organismos asociados a ellos. Pese a su importancia funcional, poco se sabe acerca de sus patrones anuales de reclutamiento. Las Islas Marietas albergan una comunidad coralina con un rico ensamblaje de holoturoideos. Con el fin de identificar los patrones de reclutamiento anuales de las especies Pentamera chierchia y Neothyone gibber, de marzo 2011 a febrero 2012 se realizaron 6 muestreos bimensuales. Se evaluó la densidad (ind $\mathrm{cm}^{-2}$ ) para cada especie y el micro-sustrato asociado. Ambas presentaron las mayores densidades durante mayo-junio $\left(N\right.$. gibber $=0.0903$ ind $\mathrm{cm}^{-2} ;$ P chierchia $=0.0396$ ind $\left.\mathrm{cm}^{-2}\right)$; durante el resto del año la densidad fue $<0.01$ ind $\mathrm{cm}^{-2}$. Este es el primer registro de P. chierchia en el área de estudio. No hubo correlación entre densidad y micro-sustrato (s $\leq$ $0.61, \mathrm{n}=7, \mathrm{p}>0.05$ ). El estudio de las fluctuaciones estacionales del reclutamiento de holoturias y su relación con factores como reproducción y disponibilidad de sustrato puede proporcionar información sobre sus ciclos de vida, dando mayor entendimiento a los patrones ecológicos de estas especies que contribuyen al mantenimiento de la biodiversidad regional.

Derechos Reservados ( 2016 Universidad Nacional Autónoma de México, Instituto de Biología. Este es un artículo de acceso abierto distribuido bajo los términos de la Licencia Creative Commons CC BY-NC-ND 4.0.

Palabras clave: Equinodermos; Dendrochirotida; Holothuroidea; Invertebrados marinos; Reproducción

\footnotetext{
* Corresponding author.

E-mail address: pao.rodriguezt@ gmail.com (A.P. Rodríguez-Troncoso).

Peer Review under the responsibility of Universidad Nacional Autónoma de México.
} 


\section{Introduction}

Recruitment is an important process that ultimately determines the population structure of most marine invertebrate species (Caley et al., 1996; Pawlik, 1992; Rodríguez, Ojeda, \& Inestrosa, 1993). Patterns of marine invertebrate reproduction and recruitment are regulated by abiotic factors, including seawater temperature, nutrient concentrations, and $\mathrm{pH}$, as well as by biotic factors such as coralline substrate availability, presence of predators, and population density (Abelson \& Denny, 1997; Broitman et al., 2008; Hadfield, 1986).

Coral communities are productive ecosystems that harbor a high biodiversity of both vertebrates and invertebrates (Glynn \& Enochs, 2011; Sheppard, Davy, \& Pilling, 2010). Holothurians represent one highly diverse and conspicuous group of such coral reef inhabitants, and they rely on reefs for food, shelter, and reproduction (Borrero-Pérez, Benavides-Serrato, \& Díaz-Sánchez, 2012; Miller \& Pawson, 1984; Uthicke, 1999). The Class Holothuroidea is represented by 6 orders: Apodida, Elasipodida, Aspidochirotida, Molpadiida, Dendrochirotida, and Dactylochirotida (Kerr, 2000; Pawson, 2007); all of them can recruit and inhabit a variety of substrates, such as mud, sand, rocks, algal beds, coral rubble, dead coral, or live coral (Alvarado \& Solís-Marín, 2013; Solís-Marín, Arriaga-Ochoa, LaguardaFigueras, Frontana-Uribe, \& Durán-González, 2009). The order Dendrochirotida is particularly well represented in coral reef ecosystems, although these sedentary, cryptic organisms can also be found in temperate areas (Bakus, 1973; Birkeland, 1989). Holothurians are an essential component of the diet of fishes, crustaceans, polychaetes, and seastars (Birkeland, 1989; Francour, 1997; Jennings \& Hunt, 2010).

Islas Marietas National Park (IMNP) represents one of the most important coral communities in the Central Mexican Pacific (CMP) region (Cupul-Magaña, Aranda, Medina-Rosas, \& Vizcaíno, 2000). The benthic structure is characterized by the presence of branching and massive corals, with the genus Pocillopora demonstrating the highest cover amongst scleractinians (Conanp, 2007; Reyes-Bonilla, Carriquiry, Leyte-Morales, \& Cupul-Magaña, 2002). Until present, a total of 38 species of holothurians have been found in reef ecosystems of the Eastern Pacific, and 13 of these are dendrochirotids (Alvarado \& Solís-Marín, 2013; Alvarado, Solís-Marín, \& Ahearn, 2010; Bastida-Zavala et al., 2013; Deichmann,1941, 1958; Maluf, 1987; Ríos-Jara, Galván-Villa, \& Solís-Marín, 2008; Ríos-Jara, Galván-Villa, Rodríguez-Zaragoza et al., 2013; Solís-Marín et al., 2009). At IMNP, 3 species of dendrochirotids have been reported: Pseudocnus californicus, Cucumaria flamma, and Neothyone gibber (Conanp, 2007; Nepote-González, 1998; Solís-Marín \& Laguarda-Figueras, 1999).

Despite the importance and prevalence of sea cucumbers in the CMP area, most prior studies have only focused on taxonomic descriptions (e.g., Caso, 1962; Conanp, 2007; Chávez-Dagostino, Nepote-González, Medina- Rosas, \& Solís-Marín, 2000; Deichmann, 1938, 1941; Nepote-González, 1998; Solís-Marín et al., 2009; Théel, 1886) or on the basic ecology of commercially valuable species (e.g., HerreroPérezrul \& Reyes-Bonilla, 2008). In contrast, few data exist about the reproductive cycle (Herrero-Pérezrul, Bonilla, García-Domínguez, \& Cintra-Buenrostro, 1999), and limited studies of their recruitment patterns have been undertaken (e.g., Aguillón-Negreros, 2011). This knowledge dearth can be attributed to the low economic value of most of the species, or to their small size, cryptic behavior, and low densities (Alvarado \& Solís-Marín, 2013). Indeed, information on invertebrate recruitment at IMNP is limited (Cruz-García, Cupul-Magaña, Hendrickx, \& Rodríguez-Troncoso, 2013; Medina-Rosas, Carriquiry, \& Cupul-Magaña, 2005) and is absent in the case of holothurians; only a few reports of the early life history stages of these organisms in the Mexican Pacific can be found (Aguillón-Negreros, 2011; Alvarado \& Solís-Marín, 2013).

The study of recruitment patterns in holothurians is important for the understanding of population structure at adult stages (Balch \& Scheibling, 2000; Caley et al., 1996); besides, this process influences the population dynamics of other species that are ecologically linked to sea cucumbers (Bakus, 1973; Birkeland, 1989; Glynn \& Enochs, 2011). Coral communities provide optimal biotic and abiotic conditions for the recruitment of many sea cucumber species (Alvarado \& Solís-Marín, 2013). In this study, the recruitment of Pentamera chierchia and N. gibber was monitored over an annual timescale in IMNP, and we also determined the influence of factors such as seasonal changes in sea surface temperature and coverage by functional groups in the benthic substrate on the recruitment pattern of both species.

\section{Materials and methods}

Islas Marietas is located at the northeastern end of Banderas Bay, México $\left(20^{\circ} 41^{\prime} 56^{\prime \prime}-20^{\circ} 41^{\prime} 53^{\prime \prime} \mathrm{N}, 105^{\circ} 35^{\prime} 02^{\prime \prime}-105^{\circ} 34^{\prime} 59^{\prime \prime}\right.$ W; Fig. 1). It consists of 2 islands of volcanic origin; with an important coral community composed by patches of Pocillopora, Porites, and Pavona, as well as sandy and rocky bottom areas (Conanp, 2007). The region is characterized by a sub-tropical climate with predominantly southeasterly winds during the day (García, 1998). The average sea surface temperature (SST) is $26.4^{\circ} \mathrm{C}$ (annual minimum $=23^{\circ} \mathrm{C}$ and maximum $=30^{\circ} \mathrm{C}$ ) and is influenced by the California Current (CC), in which cold, low salinity waters are brought in from

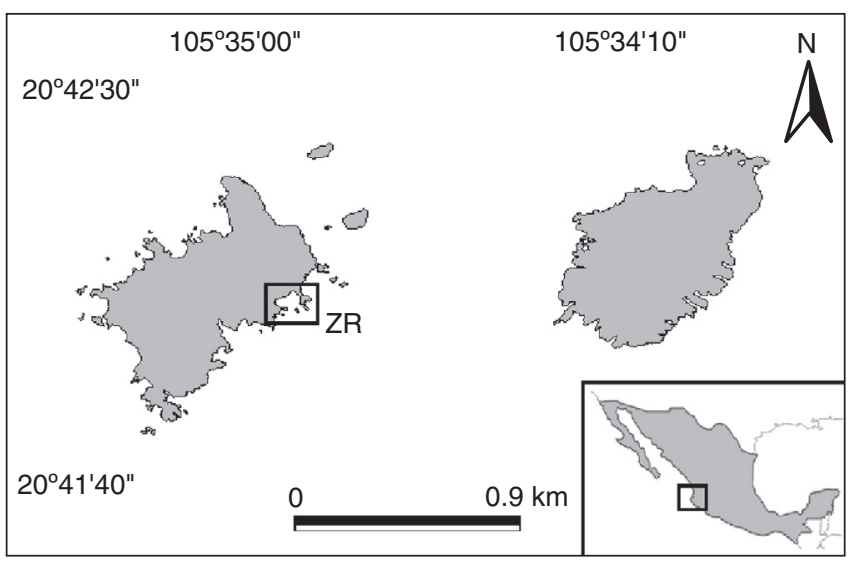

Figure 1. Study area: Islas Marietas National Park, Nayarit, Mexico. Sampling was performed in the Restoration Zone (ZR) off of Isla Larga. 
November to April. Then, the Costa Rica Coastal Current (CCR) brings in warm, high salinity water from May to October. As such, Banderas Bay is an important transitional oceanographic area (Conanp, 2007; Espino-Barr, Cabral-Solís, García-Boa, \& Puente-Gómez, 2004; Ulloa-Ramírez et al., 2008; Wyrtki, 1965).

Sampling was performed as reported by Cruz-García et al. (2013) and Sotelo-Casas, Cupul-Magaña, and RodríguezTroncoso (2014) from March 2011 to February 2012 at one reef patch located at Larga Island. Briefly, in order to generate a substrate for holothurian recruitment, 144 dead Pocillopora fragments $\sim 5 \mathrm{~cm}$ lengths were used. To eliminate any organic matter, all fragments were submerged in $10 \%$ sodium hypochlorite (in filtered seawater) for $24 \mathrm{~h}$; afterwards, the fragments were washed with freshwater for $8 \mathrm{~h}$ and dried in an oven (Precision Scientific) at $60^{\circ} \mathrm{C}$ for $24 \mathrm{~h}$. Before placing fragments, $2 \mathrm{semi}$ spherical concrete structures with 6 steel rods each were placed on a sandy bottom, located at $\sim 5 \mathrm{~m}$ depth next to the healthy Pocillopora coral colonies. Initially, a total of 24 fragments were attached to both structures; every 2 months the fragments were removed and replaced by new ones. Upon collection, fragments were placed individually in plastic bags in situ, transported to the laboratory, and preserved at $-20^{\circ} \mathrm{C}$ until further processing. Each fragment was examined, and all the holothurians were separated, identified, and counted using a stereoscopic microscope (Zeiss Stemi DR 1040) or a compound microscope (LABO), following the taxonomic criteria described by SolísMarín et al. (2009) and Prieto-Ríos (2010). The total length of each specimen was measured and individuals were dissected to locate their reproductive structures. Specimens and spicules were photo-documented using an Olympus camera and finally preserved in ethanol 70\%. Additionally, the micro-substrate adhering to the coral fragments was separated and classified into 4 functional groups: algal turf, crustose algae, bryozoans, and macroalgae, dried individually in a Precision Scientific oven at $60^{\circ} \mathrm{C}$ during $24 \mathrm{~h}$, and weighed using an analytical balance (Explorer Ohaus). Finally, the area of each coral fragment was determined using the aluminum foil method of Marsh (1970). The abundance of each species was expressed as the number of individuals per area (ind $\mathrm{cm}^{-2}$ ), and the average mass percentage of each type of micro-substrate was calculated as: (dry weight of each substrate/dry weight of total substrate)*100.

The sea surface temperature (SST) was recorded in situ every 15 -min during the 12 months of experiment using a $\mathrm{HOBO}^{\circledR}$ Pendant data logger located next to the artificial structures. Temperature data was expressed as mean temperature \pm standard error $\left({ }^{\circ} \mathrm{C} \pm \mathrm{SE}\right)$. Statistical analyses were performed using Sigmaplot (v. 11.0) software for Windows. All data were tested for normality and homogeneity of variance. As all data were not normally distributed (Shapiro-Wilk, $\mathrm{a}=0.05$ ), a Kruskal-Wallis (non-parametric, one-way ANOVA) test was calculated to determine differences between sampling times of each species; for pairwise comparisons of densities, Dunn's post hoc tests $(a=0.05)$ were performed. We assess the relation between the density of recruitment of each species with season, microsubstrate cover, and temperature using Spearman's correlations $(a=0.05)$.

\section{Results}

A total of 163 sea cucumber recruits were identified: $84 N$. gibber and 79 P. chierchia. All the organisms were classified as juveniles based on the lack of reproductive structures. Over the course of the year, the average densities of $N$. gibber and P. chierchia were 0.0156 and 0.0114 ind $\mathrm{cm}^{-2}$, respectively. For both species, higher densities were documented between May and June $\left(N\right.$. gibber $=0.0903$ ind $\mathrm{cm}^{-2} ; P$. chierchia $=0.0396$ ind $\mathrm{cm}^{-2}$ ). Mean annual SST was $26.1 \pm 0.02^{\circ} \mathrm{C}$. The minimum average temperature was recorded during March-April $\left(20.9 \pm 0.01^{\circ} \mathrm{C}\right)$, and the maxima were register during September-October with values of $30.5 \pm 0.01{ }^{\circ} \mathrm{C}$. The maximum variation between sampling bimonthly was from March-April to May-June with an increase of $\sim 6^{\circ} \mathrm{C}$ (Fig. 2).

The holothurians showed different densities of recruitment over the course of the year (Kruskal-Wallis [effect of time] for $P$. chierchia $p<0.001$, Dunn's test, $p<0.05$; Kruskal-Wallis [effect of time] for $N$. gibber $p<0.001$, Dunn's test, $p<0.05$ ). Recruitment was significantly higher in both species during May-June than the rest of the year, coinciding with an important rise of SST (Fig. 2). Except for the recruitment peak observed during May-June, both P. chierchia (from 0.00092 to $0.00839 \mathrm{ind} \mathrm{cm}^{-2}$ ) and $N$. gibber (from 0 to $0.0129 \mathrm{ind}^{-2}$ ) present low recruitment densities throughout the year. There was a total absence of recruits of $N$. gibber between November and February, coincident with the time at which lowest SSTs were registered (Fig. 2). Despite this apparent pattern, Spearman's test revealed no significant correlation between temperature and the density of either species ( $s \leq 0.58, n=6, p>0.05$ ).

A change in micro-substrata was observed over the year, with a negative correlation between the proportion of cover of algal turf and crustose algae $(s=-0.96, n=6, p<0.001)$. There was a decrease in the cover on algal turf, and the consequent increase of crustose algae during the warm season, which persisted until the temperate season during January-February (Fig. 3). Macroalgae and bryozoans substrates were found from March to June; however, they declined in the July-August sampling period and decreased to zero from September to February. There was no

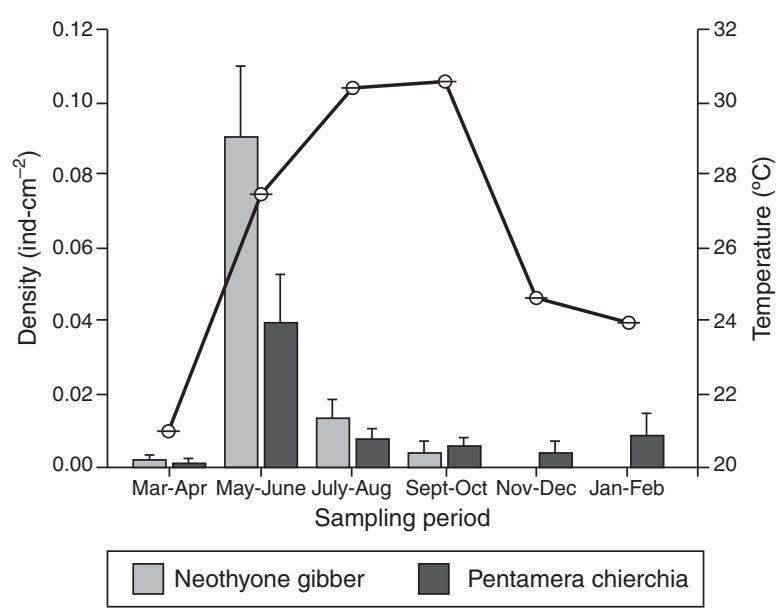

Figure 2. Temporal variation of holothurian recruitment density and mean sea surface temperature (solid line). Bars represent standard error of the mean. 


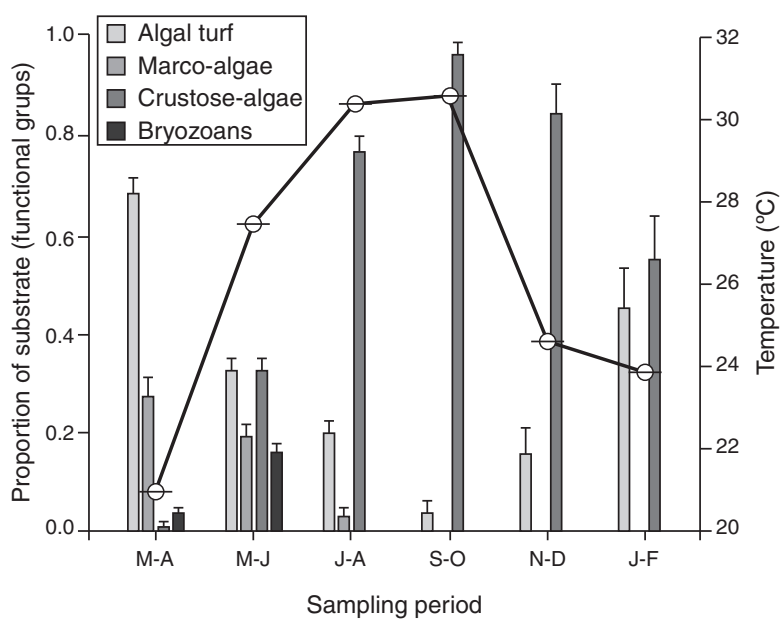

Figure 3. Proportion cover (left $y$-axis) of 4 functional categories recorded from March 2011 to February $2012(n=12)$ plotted alongside seawater temperature (solid line and right $y$-axis). Error bars represent standard error of the mean.

significant correlation between the density of recruits and the substrate $(s \leq 0.61, n=6, p>0.05)$.

\section{Discussion}

IMNP harbors a biodiverse and structure-rich coral community. The substrate coverage of this ecosystem is not only comprised of reef-building corals, but also of algae, rock, and sand; all such substrates could permit settlement by marine invertebrates (Birkeland, 1989; Cupul-Magaña et al., 2000; Chávez-Dagostino et al., 2000; Graham \& Nash, 2013). Coral reef holothurians have the ability to colonize diverse microhabitats in the reef structure, such as crevices and holes, soft bottoms, empty shells, and burrows of other organisms (Birkeland, 1989; Glynn \& Enoch, 2011). However, different species of holothurians demonstrate unique preferences for recruitment locations (Mercier, Battaglene, \& Hamel, 2000; Williams \& García-Sais, 2010), and the factors that promote the recruitment processes have not been previously studied at IMNP. Previous reports in the Mexican Pacific found that $P$. chierchia and $N$. gibber tend to recruit to calcareous substrates, such as rocks or dead coral (Alvarado \& Solís-Marín, 2013; Deichmann, 1941, 1958; Solís-Marín et al., 2009). As such, the study area provided widespread areas for recruitment of both species, the former of which had never been documented at IMNP.

Although, adults of both species were rarely seen during the majority of the year due to their cryptic nature during the day, the 2 species are considered to have a wide distribution and have been reported from several localities from Gulf of California to Peru (Deichmann, 1941; Prieto-Ríos, 2010; SolísMarín et al., 2009). The high densities of $P$. chierchia and $N$. gibber recruits at IMNP could be an indication of the role of the island as a sea cucumber nursery. The importance to identify and conserve nursery sites has been emphasized in previous studies on the Eastern Pacific (Aguillón-Negreros, 2011; ToralGranda, 2005); and therefore the Island becomes a priority area for biodiversity conservation in the CMP. In addition, the presence of $P$. chierchia in the study area fills a critical distribution gap for this species along the CMP and represents an important advance in the knowledge of the biodiversity in the region (Honey-Escandón, Solís-Marín, \& Laguarda-Figueras, 2008; Salcedo-Martínez, Green, Gamboa-Contreras, \& Gómez, 1988; Solís-Marín, Laguarda-Figueras, Durán-González, Ahearn, \& Vega, 2005; Toral-Granda, 2005).

Annual temperature fluctuations regulate certain physiological activities of invertebrates, such as reproduction and recruitment, which are triggered and favored during the warm periods (Cowen \& Sponaugle, 2009; Somero, 2005). The timing of such events is determined by the local oceanographic conditions (Broitman et al., 2008; Pineda, Reyns, \& Starczak, 2009; Roughgarden, Gaines, \& Possingham, 1988). Some species are characterized by a single spawning period during summer, which is also driven by SST changes (Herrero-Pérezrul et al., 1999). In the study area, the recruitment density of holothurians presented seasonal changes, with peaks during May-June, and low values for both species for the rest of the year. As the rate of recruitment depends on larval supply, the high densities of recruits observed in May-June may be due to a recent spawning event that occurred after the March-April sampling time; such an event may have been associated with the strong increase in SST between March-April and May-June. The lack of correlation between SST and recruitment has been previously reported for echinoids, asteroids, and holothuroids (Miller, 1995), and only associated as a determinant factor for spawning during the spring season and subsequent recruitment in summer in species such as Isostichopus fuscus and Holothuria (Selenkothuria) lubrica distributed at the Mexican Pacific (Herrero-Pérezrul et al., 1999; Skarbnik-López, Herrero-Pérezrul, Reyes-Bonilla, Domínguez, \& Morales, 2010).

Although both temperature and substrate type are important for recruitment in most invertebrates, oceanic currents, chemical signals, depth, and bottom complexity all play important roles (Abelson \& Denny, 1997; Allani \& Melloni, 1999; Broitman et al., 2008). In addition, biotic factors, such as predation, substrate preference, and food supply and endogenous factors, such as larval development strategy, duration of the competent stage, and motility (Allani \& Melloni, 1999; Hadfield, 1986; Pawlik, 1992; Poulin, Boletzky, \& Féral, 2001), have important implications for recruitment and may have accounted for some of the patterns observed at IMNP. Here, it is important to consider that the holothurians in this study settled on coral skeletal structures, suggesting this as an adequate substrate for recruitment, independent of the micro-substrate growing on top. The affinity of the sea cucumbers to this substratum can be assumed as a positive response to the available refuge, positive chemical signals or structural complexity that may be beneficial for larval survival (Poulin et al., 2001). In addition, the data show that the presence of these dendrochirotids did not depend on a specific micro-substrate, possibly due to their filter-feeding habits (Birkeland, 1989; Solís-Marín et al., 2009).

After recruitment and the initial growth phase, most sea cucumbers migrate from the site of first settlement to more secure regions, such as soft substrate, burrows, or crevices in the rocks or other cryptic environments, where there is enough 
food and adequate shelter from predators (Alvarado \& SolísMarín, 2013; Balch \& Scheibling, 2000; Young \& Chia, 1982). This cryptic behavior may explain the low densities of juveniles found after to May-June and the absence of adult holothurians in our samplings.

The data on recruitment described for $P$. chierchia and $N$. gibber provides the first insight into the understanding of recruitment dynamics of subtropical holothurians and a nonrandom preference for certain types of habitats as observed on other holothurids (Aguillón-Negreros, 2011; Wolff, Schuhbauer, \& Castrejón, 2012). The presence of recruits of holothurids associated to the coral community gives an indirect evidence that these organisms recognize appropriate environmental conditions to reproduce and settle within the site. Furthermore, the recruitment process maintains not only these 2 holothurid populations but the organisms that depend on them. The evaluation of the recruitment pattern of both species represents an increase of the knowledge of sea cucumbers in the study area and evidence of the potential of IMNP as a source of feeding, reproduction, refuge and breeding for marine invertebrates in the region.

\section{Acknowledgments}

RCSC was supported by Conacyt grant No. 291281, project PROMEP 220265 for APRT and PIFI P/PIFI-201014MSU0010Z-10 for ALCM. The authors thank the authorities of the IMNP (Conanp) for assistance and use of facilities during the sampling periods. In addition, the authors would like to thank students who contributed to the sample processing, as well as Dr. Anderson Mayfield, who carefully proofread the English.

\section{References}

Abelson, A., \& Denny, M. (1997). Settlement of marine organisms in flow. Annual Review of Ecology, Evolution, and Systematics, 28, 317-339.

Aguillón-Negreros, A. (2011). Variación espacio-temporal del reclutamiento en Mollusca y Echinodermata en la Bahía de La Paz, Baja California Sur, México. Ph.D. Thesis. La Paz, BCS: Centro Interdisciplinario de Ciencias Marinas, Instituto Politécnico Nacional.

Allani, S., \& Melloni, R. (1999). Dispersal strategies of benthic species and water current variability in the Corsica Channel (Western Mediterranean). Scientia Marina, 63, 137-145.

Alvarado, J. J., Solís-Marín, F. A., \& Ahearn, C. (2010). Echinoderms (Echinodermata) diversity off Central America Pacific. Marine Biodiversity, 40, 45-56.

Alvarado, J. J., \& Solís-Marín, F. A. (2013). Echinoderm research and diversity in Latin America. Heidelberg, Berlin: Springer.

Balch, T., \& Scheibling, R. T. (2000). Temporal and spatial variability in settlement and recruitment of echinoderms in kelp beds and barrens in Nova Scotia. Marine Ecology Progress Series, 205, 139-154.

Bastida-Zavala, J. R., García-Madrigal, M. S., Rosas-Alquicira, E. F., LópezPérez, R. A., Benítez-Villalobos, F., Meraz-Hernando, J. F., et al. (2013). Marine and coastal biodiversity of Oaxaca, Mexico. CheckList, 9, 329-390.

Bakus, G. J. (1973). The biology and ecology of tropical holothurians. In O. A. Joes, \& R. Endean (Eds.), Biology and geology of coral reefs, Vol. II Biology 1 (pp. 326-363). New York: Academic Press.

Birkeland, C. (1989). The influence of echinoderms on coral-reef communities. In M. Jangoux, \& J. Lawrence (Eds.), Echinoderm studies (Vol. 3) (pp. 1-79). Rotterdam: Balkema.
Borrero-Pérez, G. H., Benavides-Serrato, M., \& Díaz-Sánchez, C. M. (2012). Equinodermos del Caribe colombiano II: Echinoidea y Holothuroidea. Santa Marta, Colombia: Serie de Publicaciones Especiales de Invemar Núm. 30.

Broitman, B. R., Blanchette, C. A., Menge, B. A., Lubchenco, J., Krenz, C., Foley, M., et al. (2008). Spatial and temporal patterns of invertebrate recruitment along the West coast of the United States. Ecological Monographs, 78, 403-421

Caley, M. J., Carr, M. H., Hixon, M. A., Hughes, T. P., Jones, G. P., \& Menge, B. A. (1996). Recruitment and the local dynamics of open marine populations. Annual Review of Ecology, Evolution and Systematics, 27, 477-500.

Caso, M. E. (1962). Estudios sobre equinodermos de México. Contribución al conocimiento de los equinodermos de las Islas Revillagigedo. Anales del Instituto de Ciencias del Mary Limnología, Universidad Nacional Autónoma de México, 33, 293-330.

Chávez-Dagostino, R. M., Nepote-González, A. C., Medina- Rosas, P., \& Solís-Marín, F. A. (2000). Listado preliminar de echinoideos y asteroideos (Echinodermata: Echinoidea y Asteroidea) de las Islas Marietas, Nayarit, México. Mexicoa, 2, 69-72.

Conanp (Comisión Nacional de Áreas Naturales Protegidas). (2007). Programa de conservación y manejo, Parque Nacional Islas Marietas, México. México, D.F.: Comisión Nacional de Áreas Naturales Protegidas.

Cowen, R. K., \& Sponaugle, S. (2009). Larval dispersal and marine population connectivity. Annual Review of Marine Science, 1, 443-466.

Cruz-García, R., Cupul-Magaña, A. L., Hendrickx, M. E., \& RodríguezTroncoso, A. P. (2013). Abundance of three species of Isopoda (Peracarida, Isopoda) associated with a coral reef environment in Pacific Mexico. Crustaceana, 86, 1664-1674.

Cupul-Magaña, A. L., Aranda, O. S., Medina-Rosas, P., \& Vizcaíno, V. (2000). Comunidades coralinas de las Islas Marietas, Bahía de Banderas, JaliscoNayari, México. Mexicoa, 2, 15-22.

Deichmann, E. (1938). Eastern Pacific Expeditions of the New York Zoological Society. Holothurians from the western coasts of Lower California and Central America, and from Galápagos Islands. Zoologica, 23, 361-387.

Deichmann, E. (1941). The Holothuroidea collected by the "Velero" III during the years 1932 to 1938. Part I, Dendrochirotida. Allan Hancock Pacific Expedition, 8, 61-195.

Deichmann, E. (1958). The Holothurioidea collected by the Velero III and IV during the years 1932 to 1954, Part II: Aspidochirotida. Allan Hancock Pacific Expedition, 11, 253-349.

Espino-Barr, E., Cabral-Solís, E. G., García-Boa, A., \& Puente-Gómez, M. (2004). Especies marinas con valor comercial de la costa de Jalisco, México. Secretaría de Agricultura Ganadería, Desarrollo Rural, Pesca y Alimentación. Instituto Politécnico Nacional: México, D.F.

Espino-Barr, E., Cabral-Solís, E. G., García-Boa, A., \& Puente-Gómez, M. (2008). Pesca artesanal multiespecífica en la costa de Colima. Criterios biológicos para su administración. Serie Linderos de la Costa. México, D.F.: Centro Interdisciplinario de Investigaciones en Medio Ambiente y Desarrollo, Instituto Politécnico Nacional.

Francour, P. (1997). Predation on holothurians: a literature review. Invertebrate Biology, 116, 52-60.

García, E. (1998). Carta de Climas. Sistema de Koppen, modificado por E. García. Escala 1: 1000000 Conabio-Estadigrafía, México.

Glynn, P. W., \& Enochs, I. C. (2011). Invertebrates and their roles in coral reef ecosystems. In Z. Dubinsky, \& N. Stambler (Eds.), Coral reefs: an ecosystem in transition (pp. 273-325). Netherlands: Springer.

Graham, N. A. J., \& Nash, K. L. (2013). The importance of structural complexity in coral reef ecosystems. Coral Reefs, 32, 315-326.

Hadfield, M. G. (1986). Settlement and recruitment of marine invertebrates: a perspective and some proposals. Bulletin of Marine Science, 39, 418-425.

Herrero-Pérezrul, M. D., Bonilla, H. R., García-Domínguez, F., \& CintraBuenrostro, C. E. (1999). Reproduction and growth of Isostichopus fuscus (Echinodermata: Holothuroidea) in the southern Gulf of California, México. Marine Biology, 135, 521-532.

Herrero-Pérezrul, M. D., \& Reyes-Bonilla, H. (2008). Weight-length relationship and relative condition of the holothurian Isostichopus fuscus at Espiritu Santo Island, Gulf of California, México. Revista de Biología Tropical, 56, 273-280. 
Honey-Escandón, M., Solís-Marín, F. A., \& Laguarda-Figueras, A. (2008). Equinodermos (Echinodermata) del Pacífico Mexicano. Revista de Biología Tropical, 56, 57-73.

Jennings, L. B., \& Hunt, H. L. (2010). Settlement, recruitment and potential predators and competitors of juvenile echinoderms in the rocky subtidal zone. Marine Biology, 157, 307-316.

Kerr, A. M. (2000). Holothuroidea. Sea cucumbers. Version 01 December 2000. http://tolweb.org/Holothuroidea/19240/2000.12.01. In: The Tree of Life Web Project, http://tolweb.org/Last accessed 8.XI.2014.

Maluf, L. Y. (1987). Classification and distribution of the Central Eastern Pacific echinoderms. Ph.D. Thesis. Arizona: The University of Arizona.

Marsh, J. A., Jr. (1970). Primary productivity of reef-building calcareous red algae. Ecology, 51, 255-263.

Medina-Rosas, P., Carriquiry, J. D., \& Cupul-Magaña, A. L. (2005). Reclutamiento de Porites (Scleractinia) sobre sustrato artificial en arrecifes afectados por El Niño 1997-98 en Bahía de Banderas, Pacífico mexicano. Ciencias Marinas, 31, 103-109.

Mercier, A., Battaglene, S. C., \& Hamel, J. F. (2000). Settlement preferences and early migration of the tropical sea cucumber Holothuria scabra. Journal of Experimental Marine Biology and Ecology, 24, 89-110.

Miller, B. A. (1995). Larval abundance and early juvenile recruitment of echinoids, asteroids, and holothuroids on the Oregon coast. M.Sc. Thesis. Oregon: University of Oregon.

Miller, J. E., \& Pawson, D. L. (1984). Holothurians (Echinodermata: Holothuroidea). Memoirs of the Hourglass Cruises, 6, 1-79.

Nepote-González, A. C. (1998). Holoturias (Echinodermata: Holothuroidea) de las Islas Marietas, Bahía de Banderas, Jalisco-Nayarit, México. B.Sc. Thesis. Guadalajara, México: Centro Universitario de Ciencias Biológicas y Agropecuarias. Universidad de Guadalajara.

Pawlik, J. R. (1992). Chemical ecology of the settlement of benthic marine invertebrates. Oceanography and Marine Biology: An Annual Review, 30, 273-335.

Pawson, D. L. (2007). Phylum Echinodermata. Zootaxa, 1668, 749-764.

Pineda, J., Reyns, N. B., \& Starczak, V. R. (2009). Complexity and simplification in understanding recruitment in benthic populations. Population Ecology, 51, $17-32$

Poulin, E., Boletzky, S., \& Féral, J. P. (2001). Combined ecological factors permit classification of developmental patterns in benthic marine invertebrates: A discussion note. Journal of Experimental Marine Biology and Ecology, 257, 109-115

Prieto-Ríos, E. (2010). Taxonomía de Holothuroidea (Echinodermata) del mar del Perú. B.Sc. Thesis. Lima: Universidad Nacional Mayor de San Marcos.

Reyes-Bonilla, H., Carriquiry, J., Leyte-Morales, G., \& Cupul-Magaña, A. L. (2002). Effects of the El Niño-Southern oscillation and the Anti-El Niño event (1997-1999) on coral reefs of the western coast of Mexico. Coral Reefs, 21, 368-372.

Ríos-Jara, E., Galván-Villa, C. M., \& Solís-Marín, F. A. (2008). Equinodermos del Parque Nacional Isla Isabel, Nayarit, México. Revista Mexicana de la Biodiversidad, 79, 131-141.

Ríos-Jara, E., Galván-Villa, C. M., Rodríguez-Zaragoza, F. A., López-Uriarte, E., Bastida-Izaguirre, D., \& Solís-Marín, F. A. (2013). Los equinodermos (Echinodermata) de bahía Chamela, Jalisco, México. Revista Mexicana de la Biodiversidad, 84, 263-279.

Rodríguez, S. R., Ojeda, F. P., \& Inestrosa, N. C. (1993). Settlement of benthic marine invertebrates. Marine Ecology Progress Series, 97, 193-207.

Roughgarden, J., Gaines, S., \& Possingham, H. (1988). Recruitment dynamics in complex life cycles. Science, 241, 1460-1466.
Salcedo-Martínez, S., Green, G., Gamboa-Contreras, A., \& Gómez, P. (1988). Inventario de macroalgas y macroinvertebrados bénticos, presentes en áreas rocosas de la región de Zihuatanejo, Guerrero, México. Anales del Instituto de Ciencias del Mar y Limnología, Universidad Nacional Autónoma de México, 15, 73-96.

Sheppard, C. R. C., Davy, S. K., \& Pilling, G. M. (2010). The biology of coral reefs. Oxford: Oxford University Press.

Skarbnik-López, J., Herrero-Pérezrul, M. D., Reyes-Bonilla, H., Domínguez, F. G., \& Morales, J. T. (2010). Reproductive cycle of Holothuria (Selenkothuria) lubrica Selenka, 1867 (Echinodermata: Holothuroidea) in Bahía de la Paz, Mexico. In L. G. Harris, S. A. Böttger, C. W. Walker, \& M. P. Lesser (Eds.), Echinoderms: Durham, Proceedings of the 12th International Echinoderm Conference. (pp. 487-494). Balkema, Leiden: CRC Press, Taylor and Francis Group.

Solís-Marín, F. A., \& Laguarda-Figueras, A. (1999). Cucumaria flamma, a new species of sea cucumber from the central eastern Pacific (Echinodermata: Holothuroidea). Proceedings of the Biological Society of Washington, 112, 778-786.

Solís-Marín, F. A., Laguarda-Figueras, A., Durán-González, A., Ahearn, C. G., \& Vega, J. T. (2005). Equinodermos (Echinodermata) del Golfo de California, México. Revista de Biología Tropical, 53, 123-137.

Solís-Marín, F. A., Arriaga-Ochoa, J. A., Laguarda-Figueras, A., FrontanaUribe, C. S., \& Durán-González, A. (2009). Holoturoideos del Golfo de California. México, D.F.: Conabio, ICMyL-UNAM.

Somero, G. N. (2005). Linking biogeography to physiology: evolutionary and acclamatory adjustments of thermal limits. Frontiers in Zoology, 2, $1-9$

Sotelo-Casas, R. C., Cupul-Magaña, A. L., \& Rodríguez-Troncoso, A. P. (2014). Primer registro del género Clunio (Diptera: Chironomidae) asociado a las comunidades coralinas de islas Marietas, México. Revista Mexicana de Biodiversidad, 85, 14-23.

Toral-Granda, M. V. (2005). Requiem for the Galápagos sea cucumber fishery. SPC Beche-de-Mer Bulletin, 21, 5-8.

Theel, H. (1886). Report on the Holothurioidea dredged by the HMS Challenger during the years 1873-1876. Part II, Report of the Scientific Results of the Voyage of HMS Challenger 1873-1876. Zoology, 14, 1-290.

Ulloa-Ramírez, P. A., Patiño-Valencia, J. L., Guevara-Rascado, M. L., Hernández-Ventura, S., Sánchez-Regalado, R., \& Pérez-Velázquez, A. (2008). Peces marinos de valor comercial del estado de Nayarit, México. Nayarit: Instituto Nacional de la Pesca.

Uthicke, S. (1999). Sediment bioturbation and impact of feeding activity of Holothuria (Halodeima) atra and Stichopus chloronotus, two sediment feeding holothurians, at Lizard Island, Great Barrier Reef. Bulletin of Marine Science, 64, 129-141.

Williams, S. M., \& García-Sais, J. (2010). Temporal and spatial distribution patterns of echinoderm larvae in La Parguera, Puerto Rico. Revista de Biología Tropical, 58, 81-88.

Wolff, M., Schuhbauer, A., \& Castrejón, M. (2012). A revised strategy for the monitoring and management of the Galapagos sea cucumber Isostichopus fuscus (Aspidochirotida: Stichopodidae). Revista de Biología Tropical, 60, 539-551.

Wyrtki, K. (1965). Surface currents of the Eastern Tropical Pacific Ocean. InterAmerican Tropical Tuna Commission Bulletin, 9, 33-68.

Young, C. M., \& Chia, F. S. (1982). Factors controlling spatial distribution of the sea cucumber Psolus chitonoides: settling and post-settling behavior. Marine Biology, 69, 195-205. 